\title{
Arrhinolemur scalabrinii Ameghino, 1898, of the late Miocene - a taxonomic journey from the Mammalia to the Anostomidae (Ostariophysi: Characiformes)
}

\author{
Sergio Bogan ${ }^{1}$, Brian Sidlauskas ${ }^{2,3}$, Richard P. Vari ${ }^{3}$ and Federico Agnolin ${ }^{1,4}$
}

The fossil species Arrhinolemur scalabrinii, which was described from late Miocene deposits of Entre Ríos, Argentina, is reevaluated. Whereas the species was originally placed in the Primates (Mammalia) and later made the unique member of the order Arrhinolemuroidea within the Mammalia, our analysis indicates that the specimen is rather a fish of the genus Leporinus, family Anostomidae (Characiformes). The species is redescribed, and the characters that support its new generic assignment are discussed.

A espécie fóssil Arrhinolemur scalabrinii, descrita de depósitos do Mioceno Superior de Entre Ríos, Argentina, é reavaliada. Apesar da espécie ter sido originalmente incluída em Primata (Mammalia), constituindo-se posteriormente no único membro da ordem Arrhinolemuroidea dentro de Mammalia, nossa análise indica que o espécime trata-se de um peixe do gênero Leporinus, família Anostomidae (Characiformes). A espécie é redescrita, e os caracteres que fundamentam a nova posição do gênero são discutidos.

Key words: Argentina, fossil, Leporinus, Osteology, Phylogeny.

\section{Introduction}

Vertebrate remains in the fossil record are nearly invariably incomplete, an impediment that often complicates the interpretation of the phylogenetic position of many specimens. This problem results in the paleontological literature being replete with misidentifications at many taxonomic levels. Arrhinolemur scalabrinii from late Miocene deposits of central Argentina has undergone a particularly noteworthy taxonomic journey in slightly over 12 decades. The species was described by Ameghino (1898) on the basis of a single small, incomplete skull collected in the vicinity of the city of Paraná, Entre Ríos Province, Argentina. Ameghino dedicated the species to Pedro Scalabrini, a well-known collector of fossils from the region who had conveyed the specimen to him, and who was also the director of the Natural Science Museum of the city of Corrientes. Ameghino noted that the fossil was unusual in various details and initially assigned it to the primate family Lemuridae based on an apparently superficial examination of the material, which remained largely encased in sedimentary matrix. Following a partial cleaning of the skull, Ameghino (1899) commented on the differences of the cranial morphology of Arrhinolemur in comparison to all other mammals and proposed that the fossil was appropriately recognized in the Arrhinolemuroidea, a new order of bizarre fossil mammals. Nearly a half century later, Simpson (1945) briefly reviewed the holotype of Arrhinolemur and in a dramatic shift proposed that its relationships lay not with mammals, but that the fossil instead most likely represented an unidentified type of fish. Mones (1986) continued on that course of action and identified the holotype as an undetermined species of fish possibly related to the Characidae. Herein we describe and illustrate the fossil and conclude that it clearly represents a species of Leporinus, a widely distributed genus of characiform fishes within the South American family Anostomidae.

\footnotetext{
${ }^{1}$ Universidad Maimónides, Fundación de Historia Natural Félix de Azara, Área Paleontología, Departamento de Ciencias Naturales y Antropología, CEBBAD. Hidalgo 775 piso 7 (C1405BDB), Ciudad Autónoma de Buenos Aires, República Argentina. sergiobogan@yahoo.com.ar

${ }^{2}$ Oregon State University, Department of Fisheries and Wildlife, 104 Nash Hall, Corvallis, OR 97331-3803, USA. brian.sidlauskas@oregonstate.edu

${ }^{3}$ Smithsonian Institution, National Museum of Natural History, Department of Vertebrate Zoology. MRC-159, PO Box 37012, Washington, D.C. 20013-7012, USA. varir@si.edu

${ }^{4}$ Museo Argentino de Ciencias Naturales “Bernardino Rivadavia”, Laboratorio de Anatomía Comparada y Evolución de los Vertebrados, Av. Ángel Gallardo 470 (C1405BDB), Buenos Aires, Argentina.
} 


\section{Material and Methods}

The holotype and only known specimen of Arrhinolemur scalabrinii was examined in MACN (Museo Argentino de Ciencias Naturales "Bernardino Rivadavia", Buenos Aires). The fossil material consists of a threedimensional skull lacking a certain number of elements and with indications of postmortem dorsoventral compression. The dorsal portion of the skull is relatively well-preserved, with distinct sutures apparent between the bones. The left lateral region of the skull has multiple well-preserved elements including the premaxilla, dentary, nasal, lateral ethmoid, palatine and quadrate, as well as fragments of the opercle and preopercle. The epiotic, pterotic, and sphenotic are only partially preserved. The Weberian apparatus and the basioccipital are nearly totally obscured by the surrounding sedimentary matrix. The right side of the skull is rather poorly preserved with only portions of the premaxilla, dentary, sphenotic, pterotic and epiotic identifiable. A substantial portion of all those bones is still embedded in matrix. The right side of the skull is consequently not informative and was not illustrated.

The phylogenetic position of Arrhinolemur scalabrinii was assessed in the context of a recent morphological phylogenetic analysis of the Anostomidae (Sidlauskas \& Vari, 2008). The data matrix was constructed in Mesquite v. 2.74 (Maddison \& Maddison, 2010). Arrhinolemur scalabrinii was scored unambiguously for 27 characters of the neurocranium, oral jaws, dentition, palatine, quadrate and premaxilla. The other 131 characters of Sidlauskas \& Vari (2008) were coded as missing for the fossil, since they were either not preserved or embedded in the matrix. Character coding for Arrhinolemur scalabrinii following Sidlauskas \& Vari (2008): 15:1, 19:0, 27:1, 28:1, 29:0, 30:0, 31:3, 35:0, 37:0, 38:0, 39:0, 40:0, 41:1, 42:1, 44:0, 45:1, 46:1, 57:0, 58:0, 67:1, 68:1, 69:0, 70:0, 77:0, 84:1, 128:0, 132:1. Characters not listed were coded as missing. Phylogenetic analysis in PAUP* 4.0 Beta 10 (Swofford, 2003) employed parsimony with 1000 heuristic searches, each with a random sequence of taxon addition followed by tree bisection-reconnection. The program was also set to collapse zero-length branches. All characters were treated as unordered, and polymorphisms and rooting were handled as described in Sidlauskas \& Vari (2008). The tree was explored and edited in Archaeopteryx 0.968 beta (Zmasek \& Eddy, 2001; Zmasek, 2011). Comparative material including cleared and stained specimens and dried skeletons is listed in Sidlauskas \& Vari (2008).

\section{Systematic paleontology Superorder OSTARIOPHYSI \\ Order CHARACIFORMES (sensu Fink \& Fink, 1981) Family ANOSTOMIDAE \\ Genus Leporinus Agassiz in Spix \& Agassiz, 1829 Leporinus scalabrinii (Ameghino, 1898) new combination Figs. 1 and 2}

Arrhinolemur scalabrinii Ameghino, 1898
Holotype: MACN A-9880, an incomplete skull partially removed from matrix.

Locality and age. The sole known specimen of Leporinus scalabrinii was reported by Ameghino (1899) to have been collected in the region of the city of Paraná, Entre Ríos Province, Argentina. The fossil's inexact provenance is shared by many specimens of other species collected in the $19^{\text {th }}$ century from Late Miocene outcrops at the base on the cliffs near Paraná (Ameghino, 1899). Cione et al. (2000, 2009) analyzed in detail the stratigraphical position of the freshwater fish remains recovered near Paraná, and concluded that they were collected at the base of the late Miocene Ituzaingó Formation, which ranges from about 9 Ma to 6 Ma (Marshall et al., 1983).

Diagnosis. The majority of the characters proposed by Vari (1983:50) and Sidlauskas \& Vari (2008:197) as apomorphic for the Anostomidae involve soft anatomical systems or details of the skeleton either not preserved or not apparent in the holotype of Leporinus scalabrinii. However, three features of the fossil indicate that it is appropriately assigned to the Anostomidae: 1) the ascending process of the premaxilla that is large, well-developed and distinctly triangular overall (Fig. 1); 2) the chisel-shaped dentary teeth that taper to a pointed or blunt distal margin without additional cusping; and 3) the

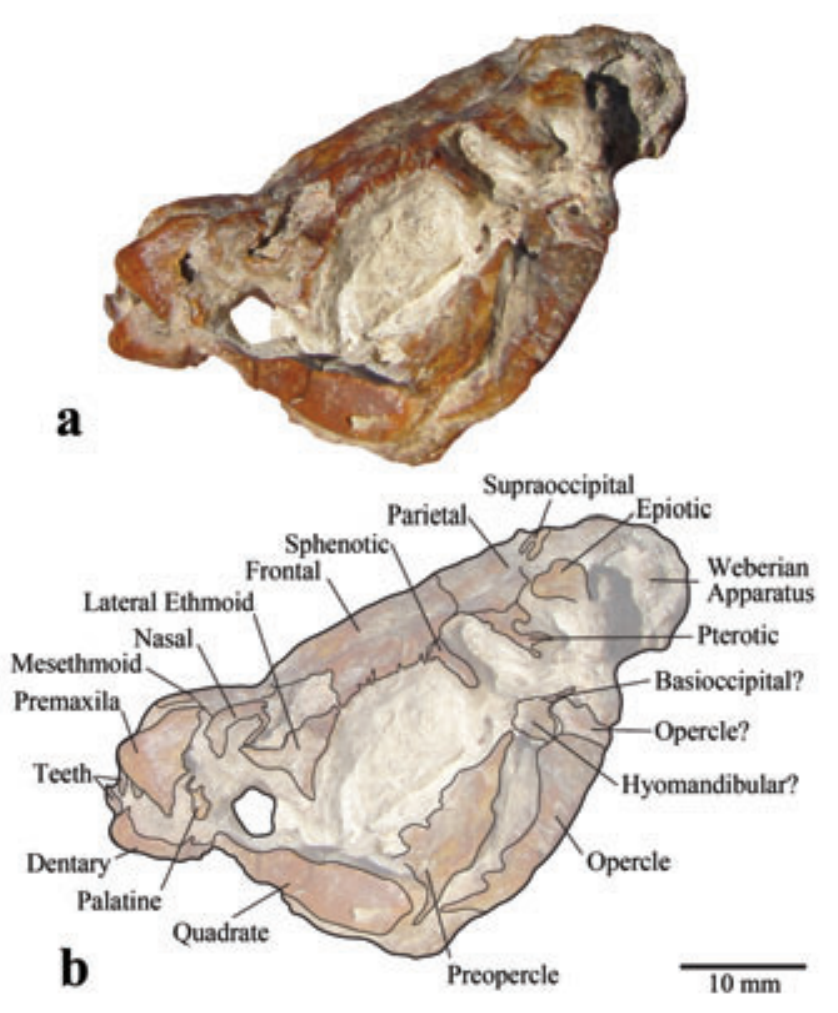

Fig. 1. Leporinus scalabrinii (MACN A-9880), holotype: a, lateral view; $\mathbf{b}$, interpretative lines of exposed portions of bones and sutures. 
presence of a shelf on the lateral surface of the preopercle that presumably served as an origin for a portion of the adductor mandibulae (Sidlauskas \& Vari, 2008, characters 37, 45 and 84 ). In addition, the overall morphology of the visible portions of the jaws, neurocranium, and suspensorium (Figs. 1-2) are comparable to that typical for many members of the Anostomidae, in particular those of Abramites and Leporinus (see illustrations in Sidlauskas \& Vari, 2008).

The combination of three premaxillary teeth (character 31), spade-shaped dentary teeth (character 37) without a distinct notch in the posterior lamina (characters 38, 39, 40), and only a single cusp on the symphyseal and second

a
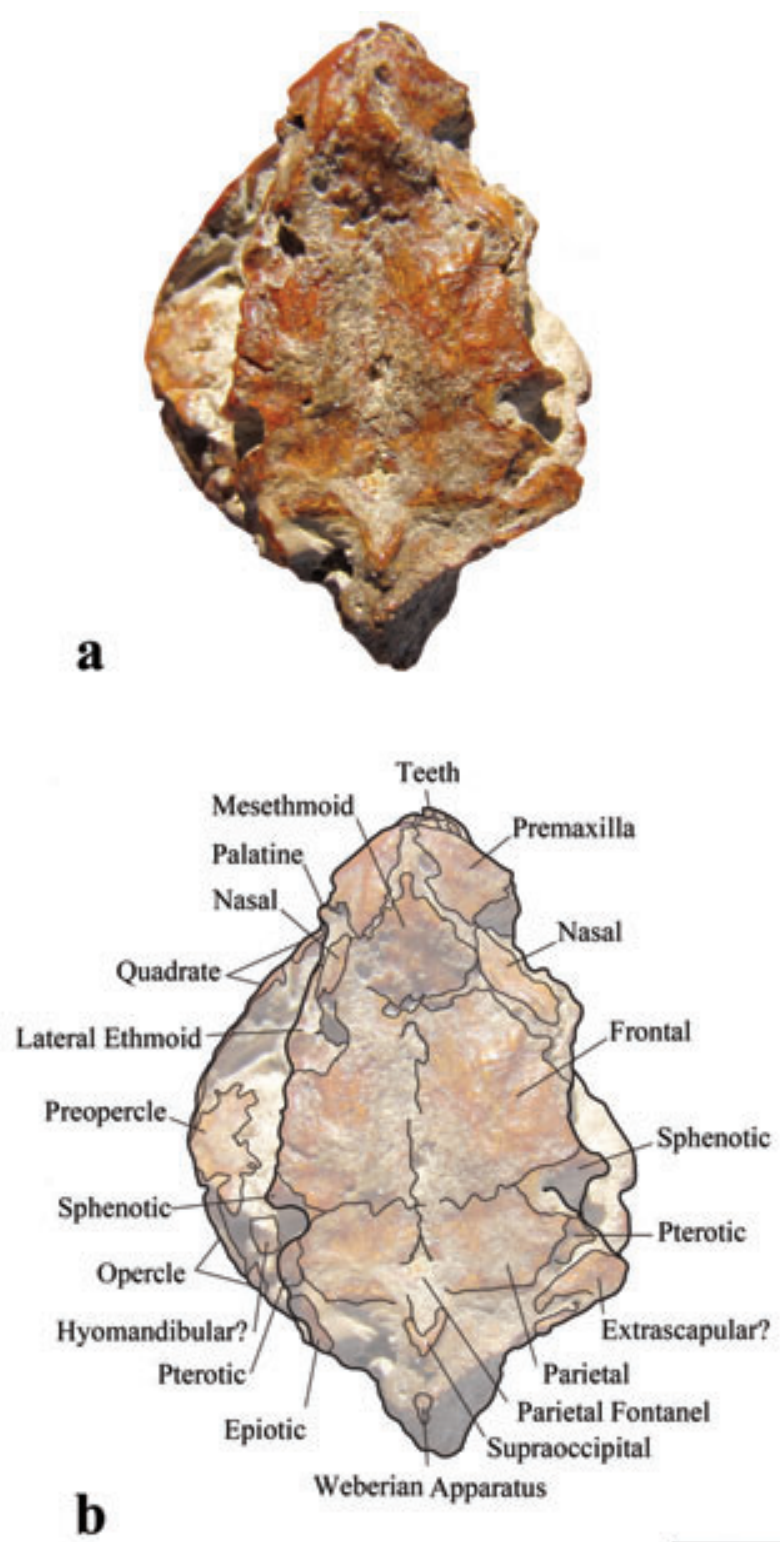

$10 \mathrm{~mm}$

Fig. 2. Leporinus scalabrinii (MACN A-9880), holotype: a, dorsal view. $\mathbf{b}$, interpretative lines of exposed portions of bones and sutures. dentary teeth (characters 41 and 42) separates the fossil from all previously examined anostomoid species except Hypomasticus megalepis (Günther, 1863) and some species of Leporinus. Leporinus scalabrinii clearly possesses a terminal mouth (Fig. 1) with an anteriorly directed anterior portion of the mesethmoid (character 15, Fig. 2) and a posterodorsally inclined premaxilla (character 46) rather than the ventrally directed and hooked mesethmoid and vertically inclined premaxilla that characterize Hypomasticus. Unusual among anostomids, Leporinus scalabrinii possesses a largely closed frontal-parietal fontanel (Fig. 2), a condition otherwise seen only in Abramites, Anostomus and some species of Pseudanos. Details of the dentition and orientation of the fossil's jaw, as well as the overall shape of the skull, and the presence of a lateral process of the palatine (character 67, Fig. 1) rule out a placement within Anostomus or Pseudanos, while the posterior laminae of the dentary teeth in Leporinus scalabrinii lack the deep notch separating the tooth into anterior and posterior lobes that characterizes Abramites. Leporinus scalabrinii therefore possesses a unique combination of character states and merits recognition as a valid species.

Description. The holotype is partially dorsoventrally compressed with the portions of the suspensorium of the left side splayed laterally (Fig. 2). The postmortem compression of the specimen, as evidenced by the displacement of those elements, also likely resulted in the dorsal flexure of the mesethmoid and jaws relative to the typical position in other members of the Anostomidae (Fig. 1 ). Due to the unique nature of the specimen, it was not feasible to remove residual matrix, but a number of features apparent on the specimen are described in the following sections.

Dorsal portion of skull. The mesethmoid has a narrow anterior process extending between the ascending processes of the contralateral premaxillae and posteriorly borders the anterior portions of the paired frontals along a transverse joint (Fig. 2). Overall the bone is slightly wider than long. The distinct anterodorsal flexure of the mesethmoid relative to the frontal and more posterior portions of the skull along that joint-line likely represents postmortem deformation with such an orientation absent or less pronounced in other anostomids (Sidlauskas \& Vari, 2008, Figs. 16-18). In life, the premaxillae were likely posterodorsally inclined, resulting in a terminal mouth position. Residual matrix obscures parts of the frontals along their midlines, but the median frontal-parietal fontanel that typically completely separates those bones in many members of the family (Sidlauskas \& Vari, 2008, fig. 28) appears absent, with this particularly apparent along the posterior portion of the frontals which is the last portion of the fontanel present between those bones when the opening is retained. The area of contact between the frontals is depressed ventrally with the bones in contact via a suture, with that form of contact further evidence of the lack of a frontal fontanel in life (Fig. 1). An 
irregular transverse suture joins the frontals posteriorly to the parietals (Fig. 2). As is the case with the frontals, the parietals are also in contact along most of the midline, but have a small posterior fontanel proximate to the supraoccipital which, in turn, terminates posteromedially in a short spine (Fig. 2), with the overall morphology of the parietals being very similar to the condition present in Abramites hypselonotus. A ventrally tapering lateral ethmoid is present along the anterior margin of the orbit (Figs. 1-2), but most details of the bone are not apparent due to poor preservation and it is impossible to determine whether it bears the anterior notch present in many anostomids. The spine of the sphenotic is apparent posterior to the orbit with this followed posteriorly by the dilatator fossa and then the ventrally narrowing pterotic (Fig. 2). An ossification on the posterior right side of the braincase may represent the extrascapular or possibly a portion of the posttemporal, but the overlying covering of matrix makes a definitive assessment impossible (Fig. 2).

Jaws and teeth. As noted above, the mesethmoid and jaws are apparently reoriented anterodorsally as a consequence of postmortem deformation of the specimen. Allowing for that distortion, it would appear that the mouth was terminal in life. Each premaxilla has a strong ascending process and the main body of the ossification extends posteroventrally for a distance approximately equivalent to the length of the ascending process. Three robust teeth are present on each premaxilla, with the anteriormost the longest and the following teeth progressively less apparent. The posteriormost tooth is anteroposteriorly lengthened with a straight chisel-like cutting edge along most of its length. A strong symphyseal tooth is present on the dentary and tapers distally. A second, similarly shaped dentary tooth is visible on the right side of the specimen. This tooth is distinctly wider than high. Both teeth of the right dentary are anterodorsally oriented. Given the length of the dentary, it seems unlikely that it could potentially accommodate more than three or four teeth, a count comparable to that in many other anostomids (Sidlauskas \& Vari, 2008:106).

Infraorbital series. The infraorbital series apparently was not preserved, except for ossifications on both sides anterior to the orbit that likely represent the nasals (Figs. 1-2).

Suspensorium. The large ossification apparent on the left ventral side of the specimen is the lateral shelf of the quadrate (Fig. 1; Sidlauskas \& Vari, 2008, characters 77 and 132), which articulates with the lateral shelf of the preopercle posteriorly (Sidlauskas \& Vari, 2008, character 84). A ventrally displaced preopercle can be seen running posterodorsally from its contact with the quadrate towards the dilatator fossa (Fig. 1). A fragmentary opercle is positioned posteroventral of the preopercle (Fig. 1). The whole left suspensorium is bowed out laterally relative to its probable orientation in life. A laterally directed process of the palatine, a characteristic found only in specimens of Anostomoides, Laemolyta, Leporinus (most species), Rhytiodus, and Schizodon (see discussion of characters 67 and 68 of Sidlauskas \& Vari, 2008), appears just posterior to the posteroventral corner of the premaxilla (Fig 1).

Other portions of the skull, jaws and suspensorium are lacking or embedded in the remaining matrix.

\section{Discussion}

The phylogenetic analysis resulted in 1228 equally most parsimonious trees of 529 steps, all of which recovered $L$. scalabrinii as the sister group of Abramites hypselonotus (Günther, 1868) (Fig. 3), with that pair of taxa sister to Leporinus striatus Kner, 1858. Although poor preservation precluded coding the fossil for most characters described by Sidlauskas \& Vari (2008), a substantial portion of the dentition, neurocranium, and oral jaws was visible. Parsimony-based optimizations of characters in those systems on the consensus tree (Fig. 3) revealed a single synapomorphy for the clade composed of $L$. striatus, $L$. scalabrinii, and A. hypselonotus (character 31, three premaxillary teeth), and a single synapomorphy supporting the sister-group relationship between $L$. scalabrinii and A. hypselonotus (character 28, partial or complete closure of frontal-parietal fontanel). Several other synapomorphies linking Abramites and Leporinus striatus are discussed in Sidlauskas \& Vari (2008), but these could not be coded for L. scalabrinii. Because the fossil lacks some of the diagnostic features of Abramites, most notably the distinctive dentary tooth form that characterizes that genus (Sidlauskas \& Vari, 2008, fig. 32B), its placement in the paraphyletic genus Leporinus is most appropriate. We also note that among all Recent anostomids examined, the skull of $L$. scalabrinii is most similar to that of $L$. striatus in terms of overall morphology.

Leporinus scalabrinii extends the fossil record of the Anostomidae in Argentina to the late Miocene. Previous records of the family from deposits in Buenos Aires were all from Pleistocene and Holocene formations (Tonni \& Cione, 1984; Fucks \& Deschamps, 2008; Bogan \& Jofré, 2009). On a continental scale, fossils previously assignable to the Anostomidae based on isolated teeth are known from the Miocene deposits of the Cuenca basin of southern Ecuador (Roberts, 1975: 261) which date to approximately $19 \mathrm{Ma}$, and from the La Venta Formation in Colombia (Lundberg, 1997:73) which date to approximately 11.5 Ma (Guerrero, 1997: 41). Fossils assigned to the Anostomidae or Leporinus have also been reported from early to late Miocene deposits in Solimões/Pebas Formation of the northwestern portion of the Amazon basin (Monsch, 1998:39). Although it is not the most ancient record of the Anostomidae, or for that matter of Leporinus, L. scalabrinii is particularly valuable in providing independent confirmation of the presence of the genus based on a skull rather than on isolated teeth. 


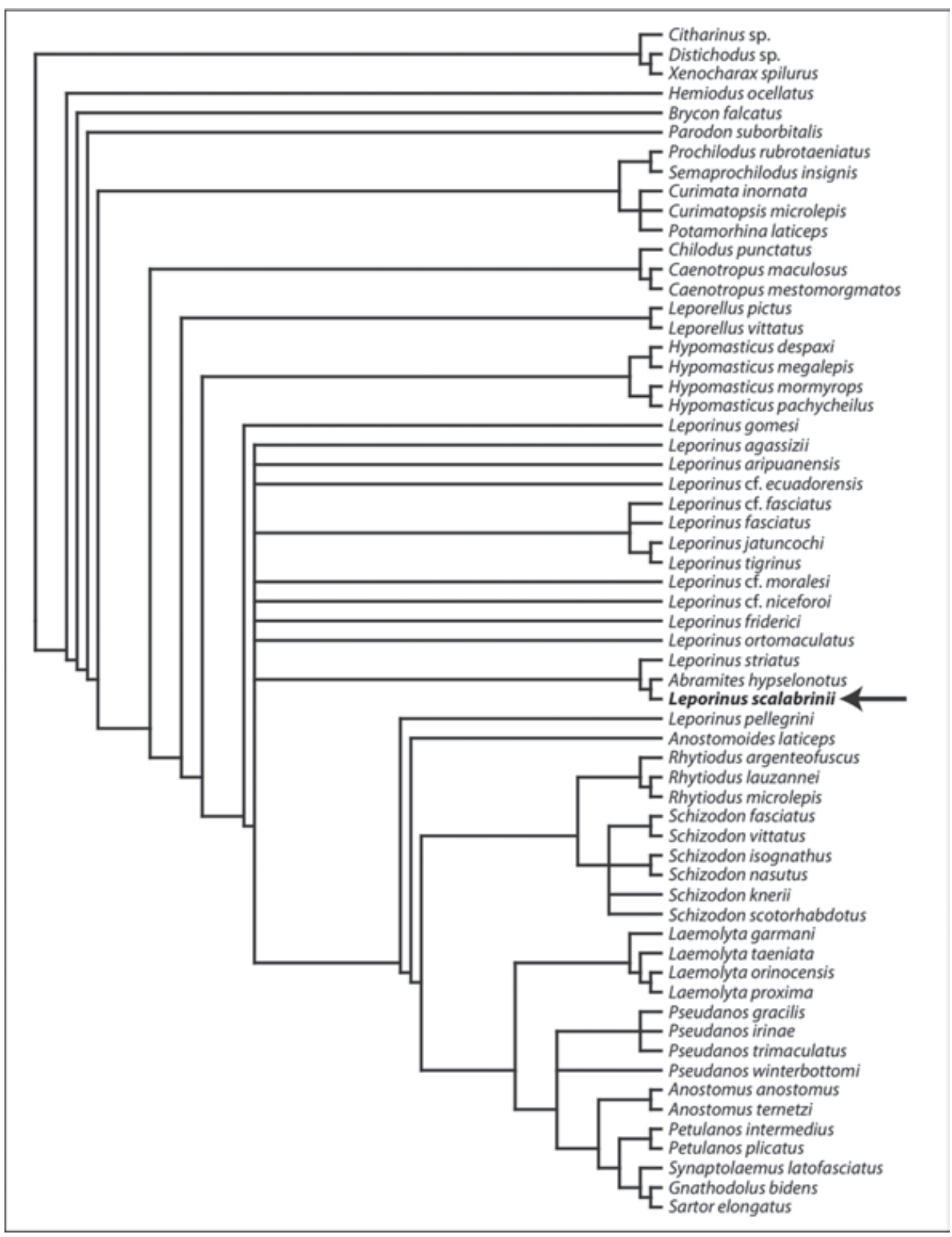

Fig. 3. Phylogenetic position of Leporinus scalabrinii based on parsimony analysis of 158 characters described by Sidlauskas \& Vari (2008), 27 of which could be unambiguously coded for the fossil (see Material and Methods for additional details.)

\section{Acknowledgements}

We thank Fernando Novas for allowing us to study the material, and Mario Sevilla and Sebastián Suárez for their help with tomographic images taken at Maimónides University. Comments from José Birindelli (MZUSP) and an anonymous reviewer helped to improve the manuscript. Adrián Giacchino (FHNFA) kindly provided logistic and financial support. 


\section{Literature Cited}

Ameghino F. 1898. Sur l'Arrhinolemur, mammifére aberrant du tertiare du Paraná. Comptes Rendus de l'Académie des Sciences, 127: 395-396.

Ameghino F. 1899. Los Arrhinolemuroidea, un nuevo orden de mamíferos extinguidos. Comunicaciones del Museo Nacional de Buenos Aires, 1: 146-151.

Bogan, S. \& G. Jofré. 2009. Ictiofauna y herpetofauna continental pleistocena del río Reconquista en el Partido de Merlo, Buenos Aires. Jornadas Paleontológicas del Centro, Olavarría, 16-17.

Cione, A. L., M. M. Azpelicueta, M. Bond, A. A. Carlini, J. R. Casciotta, M. A. Cozzuol, M. de la Fuente, Z. Gasparini, F. J. Goin, J. Noriega, G. J. Scillato-Yané, L. Soibelzon, E. P. Tonni, D. Verzi, \& M. G. Vucetich. 2000. Miocene vertebrates from Entre Ríos Province, eastern Argentina. Pp. 191-237. In: Aceñolaza, F. G. \& R. Herbst (Eds.). El Neógeno de Argentina. INSUGEO Serie Correlación Geológica, 14.

Cione, A. L., W. M. Dahdul, J. G. Lundberg \& A. Machado-Allison. 2009. Megapiranha paranensis, a new genus and species of Serrasalmidae (Characiformes, Teleostei) from the Upper Miocene of Argentina. Journal of Vertebrate Paleontology, 29: 350-358.

Fucks, E. \& C. M. Deschamps. 2008. Depósitos continentales cuaternarios en el noroeste de la provincia de Buenos Aires. Revista de la Asociacion Geologica Argentina, 63: 326-343.

Guerrero, J. 1997. Stratigraphy, sedimentary environments, and Miocene uplift of the Colombian Andes. Pp. 15-43. In: Kay, R. F., R. L. Madden, R. H. Cifelli \& J. J. Flynn (Eds.). Vertebrate paleontology in the Neotropics. The Miocene fauna of La Venta. Smithsonian Institution Press, 608p.

Lundberg, J. 1997. Fishes of the La Venta fauna: additional taxa, biotic and paleoenviromental implications. Pp. 67-91. In: R. F. Kay, R. L. Madden, R. H. Cifelli \& J. J. Flynn (Eds.). Vertebrate paleontology in the Neotropics. The Miocene fauna of La Venta. Smithsonian Institution Press, 608p.

Maddison, W. P. \& D. R. Maddison. 2010. Mesquite: a modular system for evolutionary analysis. Version 2.74. Available at http://mesquiteproject.org

Marshall, L., R. Hoffstetter \& R. Pascual. 1983. Mammals and stratigraphy: geochronology of the continental mammal-bearing Tertiary of South America. Palaeovertebrata Mémoire Extraordinaire, 1-93.
Mones, A. 1986. Paleovertebrata Sudamericana. Catálogo sistemático de los vertebrados fósiles de América del Sur. Parte I. Lista preliminar y Bibliografía. Courier Forschungsinstitut Senckenberg, 82: 1-625.

Monsch, K. A. 1998. Miocene fish faunas from the northwestern Amazonía basin (Colombia, Perú, Brasil) with evidence of marine incursions. Palaeogeography, Palaeoclimatology, Palaeoecology, 143: 31-50.

Roberts, T. 1975. Characoid fish teeth from Miocene deposits in the Cuenca basin. Journal of Zoology (London), 175: 259-271.

Sidlauskas, B. L. \& R. P. Vari. 2008. Phylogenetic relationships within the South American fish family Anostomidae (Teleostei, Ostariophysi, Characiformes). Zoological Journal of the Linnean Society, 154: 70-210.

Simpson, G. G. 1945. The principles of classification and a classification of Mammals. Bulletin of the American Museum of Natural History, 85: 1-350.

Swofford, D. 2003. PAUP*: Phylogenetic analysis using parsimony (* and other methods). Version 4. Sinauer Associates, Inc., Sunderland, MA.

Tonni, E. P. \& A. L. Cione. 1984. A thanatocenosis of continental and marine vertebrates in the Las Escobas Formation (Holocene) of Northeastern Buenos Aires province, Argentina. Quaternary of South America and Antarctic Peninsula, 2: 93-113.

Vari, R. P. 1983. Phylogenetic relationships of the families Curimatidae, Prochilodontidae, Anostomidae and Chilodontidae (Pisces, Characiformes). Smithsonian Contributions to Zoology, 378: 1-59.

Zmasek, C. M. 2011. Archaeopteryx v. 0.968 beta BG. Available at http://www.phylosoft.org/archaeopteryx/

Zmasek, C. M., \& S. R. Eddy. 2001. ATV: display and manipulation of annotated phylogenetic trees. Bioinformatics, 17: 383-384.

Submitted February 16, 2012 Accepted June 25, 2012 Published September 28, 2012 